International Journal of Library \& Information Science (IJLIS)

Volume 8, Issue 2, May-August 2019, pp. 01-08, Article ID: IJLIS_08_02_001

Available online at

http://iaeme.com/Home/issue/IJLIS?Volume=8\&Issue $=2$

Journal Impact Factor (2019): 9.8614 (Calculated by GISI) www.jifactor.com

ISSN Print: 2277-3533 and ISSN Online: 2277-3584

(C) IAEME Publication

\title{
EFFECT OF DIGITAL LITERACY ON INFORMATION SEEKING BEHAVIOUR AMONG MANAGERS OF TELECOMMUNICATION COMPANIES IN SAUDI ARABIA
}

\author{
Hashem Hussein Al Attas \\ Deanship of Library Affairs, King Fahd University of Petroleum \& Minerals \\ Dhahran Saudi Arabia
}

\begin{abstract}
This paper highlights the effect of Digital literacy on digital information seeking behaviour and use among managers of telecommunication companies in Saudi Arabia. The study adopts a quantitative research approach. The researcher uses information from the survey to generalise findings from a sample to a population. A sample size of 500 was anticipated from the total population of approximately 850 managers from the four telecommunication companies. For the primary data collection in this study, a survey questionnaire was employed. The findings indicate a positive effect of digital literacy. The emergence of digital information disseminations in a digital knowledgebased system yielded improved skills and capabilities for both individuals and organisations in information use. The use of a single-informant method, a crosssectional research design and a focus on four telecommunication companies in Saudi Arabia are the constraints of this study.
\end{abstract}

Key words: Digital Literacy, Information Seeking Behaviour, Telecommunication, Manager

Cite this Article: Hashem Hussein Al Attas, Effect of digital Literacy on information seeking behaviour among managers of telecommunication companies in Saudi Arabia, International Journal of Library \& Information Science, 8(2), 2019, pp. 01-08. http://iaeme.com/Home/issue/IJLIS?Volume $=8 \&$ Issue $=2$

\section{INTRODUCTION}

With the development of information and communication technologies (ICTs), and rapidly evolving digital media, coupled with the use of electronic resources, managers have access to diverse sources and a vast flow of information via the Internet, Intranet, corporate or enterprise portals, websites, online databases, e-communities, blogs and other e-modes, which enables them to rapidly and inexpensively communicate and exchange data. 
The ability to find, evaluate, share and create content using information technologies and the internet is called Digital literacy. According to Huerta and Sandoval-Almazn "Digital literacy is variously referred to as Internet literacy, multimedia literacy, cyber literacy, online literacy, and information literacy." (Noh, 2017)

Previous studies show that digital literacy is referred to as a person's ability to critically navigate and effectively perform tasks using digital technology, communication networks and tools (Eshet-Alkalai, 2004). Digital literacy of managers with respect to information seeking and use entails the awareness, attitude, and ability to understand and use information using different approaches, which are acquired from different sources when they are presented via computers (Katz, 2007).

Over the last few decades, many changes have occurred in the workplace, which requires paradigm shifts in managerial practices. The emergence and extensive use of information and communication technology has significantly impacted the workplace (de Alwis, 2006). Organisations continue to search for ways to improve the efficiency of their new product development to ensure their survival, competitive advantage and sustainable growth.

The gradual transformation of the work environment into a digital or networked work environment inevitably trigger changes in organisational communication processes, information flows, and structures. This study aimed to examine the mediating effect of Usefulness and Easeof use on the relationship between digital literacy and digital information seeking behaviour and use among managers of telecommunication companies in Saudi Arabia.

\section{LITERATURE REVIEW}

Information use is part of a dynamic and interactive process that evolves as managers engage in seeking information. Long \& Shrikhande, 2005) studied the course of how formal information literacy instruction in the business school classroom at the graduate and undergraduate level impacts information-seeking behaviour of the students. Based on the differences noted in different Stages for the undergraduate and graduate students, it was clear that information literacy training positively impacts student team performance. The additional improvements in performance observed in other Stages for the undergraduate students and graduate students illustrates the benefits of actively using feedback received from the students for improving the package of teaching methods over multiple semesters.

Another study conducted by Bilawar, Pujar, Librarian, \& Balasaheb, 2016) on impact of einformation literacy on information seeking behaviour of University teachers highlights that the knowledge of e-resources and training impacts information seeking behaviour and empowers users to understand about the use of information in an effective way.

Yet another study conducted by (Noh, 2017), evaluates digital literacy of college students. The evaluation areas applied in this study are roughly classified into technical literacy, bit literacy, and virtual community literacy, and each of these has five sub-groups. This study used a survey, as did much of the previous research. College students from five different colleges were targeted, with 221 surveys out of 250 returned, a return rate of $88.4 \%$. As to results, bit literacy influences information use behaviour most, followed by virtual community literacy and technical literacy in that order. Bit literacy is related to the ability to use information including information search, information discernment, editing information, processing information, and utilizing information, and these items appear to have influenced information use behaviour most. Examination of these detailed items shows that the ability to process information has the most significant effect on information use behaviour followed by information discernment, information editing, community analysis, document editing, and use of tools and ability to create cyber culture in that order. 
Ge, 2009) examines the information-seeking behaviour of scholars in e social sciences and humanities and extends the avid Ellis model of information-seeking behaviour for social scientists, which includes six characteristics: starting, chaining, browsing, differentiating, monitoring, and extracting.

\section{METHOD}

\subsection{Study design}

A deceptive cross-sectional correlation study, using survey questionnaire was conducted among to assess the association among study variables.

\subsection{Study setting and sample}

The sample for the study is obtained from managers of four telecommunication companies in Saudi Arabian from August 2013 until February 2014.

\subsection{Measurements}

To test the proposed research hypotheses, multi-item scales were adopted from previous studies to measure the constructs. The digital literacy and digital information seeking behaviour were measured by 13 item rated using a five-point Likert-type scale, which ranged from 1 (strongly disagree) to 5 (strongly agree) and was adopted from (Igbaria and Parasurman, 1989). Studies that use a similar scale indicate an acceptable internal consistency of the scale with an alpha ranging from .80 to .90 (Choudhury, 2013). Pilot study was conducted with twenty respondents, and the reliability of the instrument was measured; all alpha values exceed .70, which is suitable for these scaled items.

\subsection{Data Collection}

The questionnaires were distributed to managers using two approaches. The first approach is a direct face-to-face and hand-to-hand method, and the second approach is postal mail. The reason for selecting these methods is to ensure full coverage of the managers within the four Saudi Arabian telecommunication companies. Managers were given the questionnaire on working days during working hours. After approximately two weeks after the questionnaire was mailed to some managers, follow-up telephone calls were made to the managers who had not responded to verify that they had received the questionnaire and remind them of the importance of the study. After one month, these follow-up calls proved important but were not always successful. After two months, the last follow-up call was performed. Generally, followup was performed on a regular basis in person or via email or postal mail.

\subsection{Data Analysis and Presentation of Results}

Completed questionnaires were coded and entered into SPPS version 22. Descriptive analysis "frequency, percentage, mean, and standard deviation" was applied to descript the respondents' demographic profile, and study variables. Furthermore, linear regression analysis was conducted to test the hypothesis, the significant level set at $\mathrm{p}<0.05$.

\section{RESULTS}

\subsection{Demographic profile}

The demographic variables of the respondents are presented in Table 1. A total of 166 males participated in this survey, which represents $80 \%$ of the total respondents. The remaining 
respondents, who are 41-year-old females, comprise $20 \%$ of the total respondents. In terms of age groups, the age of approximately $43.5 \%$ of the respondent ranges from 20-30 years, and the age of approximately $38.6 \%$ of the respondents range from 31-40 years. An investigation of the level of education results reveals that $50.7 \%$ of the respondents are university graduates. The number of respondents who possess bachelor's degrees and master's degrees are almost equal (22.7\% and $20.3 \%$, respectively). A total of $45.4 \%$ of the respondents have 3 to 6 years of work experience, whereas $39.6 \%$ of the respondents have worked for less than 3 years. The largest percentage of respondents $(58.9 \%)$ work at the top management level. The percentages of middle managers and supervisory managers are almost equal $(21.3 \%$ and $19.8 \%$, respectively). All respondents use a computer and the Internet in their duties. Approximately $44.4 \%$ of respondents use word processing software, and $21.3 \%$ and $22.7 \%$ of respondents also use spreadsheet and database management software.

Table 1 Demographic Characteristics

\begin{tabular}{|c|c|}
\hline Demographic Variables & n(\%) \\
\hline \multicolumn{2}{|l|}{ Gender } \\
\hline Male & $166(80)$ \\
\hline Female & $41(20)$ \\
\hline \multicolumn{2}{|l|}{ Age group } \\
\hline $20-30$ years & $90(43.5)$ \\
\hline $31-40$ years & $80(38.6)$ \\
\hline $41-50$ years & $37(17.9)$ \\
\hline \multicolumn{2}{|l|}{ Experience } \\
\hline$<3$ years & $82(39.6)$ \\
\hline $3-6$ years & $94(45.4)$ \\
\hline$>6$ years & $31(15)$ \\
\hline \multicolumn{2}{|l|}{ Education } \\
\hline Diploma & $105(50.7)$ \\
\hline Bachelor's degree & $47(22.7)$ \\
\hline Master's degree & $42(20.3)$ \\
\hline $\mathrm{PhD}$ & $8(3.9)$ \\
\hline Others & $5(2.4)$ \\
\hline \multicolumn{2}{|l|}{ Management level } \\
\hline Top management & $122(58.9)$ \\
\hline Middle management & $44(21.3)$ \\
\hline Supervisory & $41(19.8)$ \\
\hline \multicolumn{2}{|l|}{ Computer and Internet } \\
\hline Yes & $207(100)$ \\
\hline No & $0(0)$ \\
\hline \multicolumn{2}{|l|}{ Currently use } \\
\hline Yes & $207(100)$ \\
\hline No & $0(0)$ \\
\hline \multicolumn{2}{|l|}{ Software } \\
\hline Word processing & $92(44.4)$ \\
\hline Spreadsheet & $44(21.3)$ \\
\hline Database management & $47(22.7)$ \\
\hline Application packages & $24(11.6)$ \\
\hline
\end{tabular}


Effect of digital Literacy on information seeking behaviour among managers of telecommunication companies in Saudi Arabia

\subsection{Digital literacy}

The digital literacy was measured by 5 items using a 5-point Likert scale, which ranged from "strongly disagree" to "strongly agree". Table 2 showed the descriptive result of digital literacy indicated that the majority of the respondents were disagreed and strongly disagreed with all the statements of digital literacy. .

Table 2 The descriptive profile of the responses for digital literacy

\begin{tabular}{|c|c|c|c|c|c|}
\hline Items & $\begin{array}{c}\text { Strongly } \\
\text { Agree } \mathrm{n}(\%)\end{array}$ & Agree $\mathrm{n}(\%)$ & $\begin{array}{c}\text { Neutral n } \\
(\%)\end{array}$ & $\begin{array}{c}\text { Disagree n } \\
(\%)\end{array}$ & $\begin{array}{c}\text { Strongly } \\
\text { Disagree } \mathrm{n} \\
(\%)\end{array}$ \\
\hline $\begin{array}{c}\text { I am familiar with the computer and the } \\
\text { Internet. }\end{array}$ & $9(4.35)$ & $3(1.45)$ & $33(15.94)$ & $139(67.15)$ & $23(11.11)$ \\
\hline $\begin{array}{c}\text { I can perform at least one task using the } \\
\text { computer and the Internet. }\end{array}$ & $7(3.38)$ & $3(1.45)$ & $29(14.01)$ & $135(65.22)$ & $33(15.94)$ \\
\hline $\begin{array}{c}\text { I am satisfied with the availability of } \\
\text { digital resources. }\end{array}$ & $9(4.35)$ & $3(1.45)$ & $29(14.01)$ & $122(58.94)$ & $44(21.26)$ \\
\hline $\begin{array}{c}\text { I can easily navigate digital information } \\
\text { sites. }\end{array}$ & $7(3.38)$ & $20.97)$ & $27(13.04)$ & $130(62.80)$ & $41(19.81)$ \\
\hline $\begin{array}{c}\text { I am familiar with digital tools such as } \\
\text { email, blogs and advance searches. }\end{array}$ & $8(3.86)$ & $5(2.42)$ & $19(9.18)$ & $133(64.25)$ & $42(20.29)$ \\
\hline
\end{tabular}

A CFA was conducted to validate the measurement of the digital literacy as a technical factor. All five items yielded acceptable factor loadings, which ranged from 0.66 to 0.85 Figure 1. Furthermore the CFA result indicated all the fit indices for the model was met (Table 3)

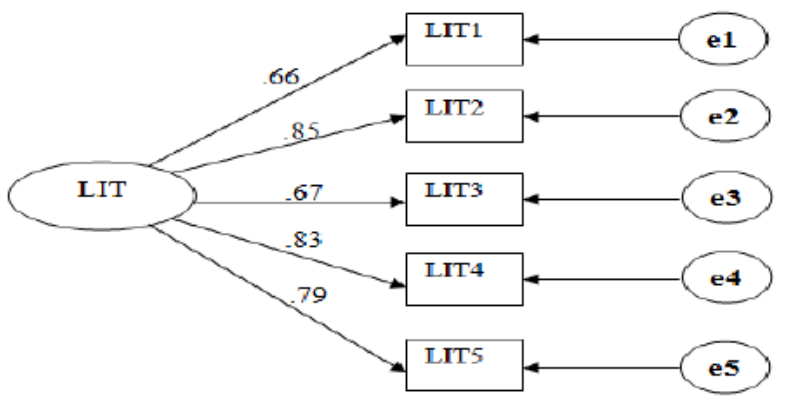

Figure 1 Measurement Model for Digital Literacy

Table 3 Model Fit Indices for Digital Literacy Construct

\begin{tabular}{|c|c|c|c|}
\hline Indices & Value & Indices & Value \\
\hline Chi-Square & 1.798 & GFI & 0.997 \\
\hline DF & 5 & TLI & 1.013 \\
\hline Ratio & 0.360 & RMSEA & 0.000 \\
\hline P Value & 0.876 & & \\
\hline
\end{tabular}

\subsection{Information Seeking Behaviour and Use}

In terms of information seeking behaviour and use, 8 items rated using 5-point Likert Scale, which ranged from "strongly disagree" to "strongly agree" were used to assess the information seeking behaviour and use. Majority of the respondents were strongly agreed and agreed with all the statements related to for information seeking behaviour and use (Table 4). 
Table 4 The descriptive profile of the responses for information seeking behaviour

\begin{tabular}{|c|c|c|c|c|c|}
\hline Items & $\begin{array}{c}\text { Strongly } \\
\text { Agree n } \\
(\%)\end{array}$ & $\begin{array}{l}\text { Agree n } \\
(\%)\end{array}$ & $\begin{array}{c}\text { Neutral n } \\
(\%)\end{array}$ & $\begin{array}{c}\text { Disagree n } \\
(\%)\end{array}$ & \begin{tabular}{|c|} 
Strongly \\
Disagree n \\
$(\%)$ \\
\end{tabular} \\
\hline $\begin{array}{l}\text { I select and use digital information that } \\
\text { corresponds with my own opinion. }\end{array}$ & $93(44.9)$ & $99(47.8)$ & $13(6.3)$ & $1(0.5)$ & $1(0.5)$ \\
\hline $\begin{array}{l}\text { I refine my search to reduce the number of } \\
\text { hits. }\end{array}$ & $98(47.3)$ & $100(48.3)$ & $8(3.9)$ & $1(0.5)$ & $0(0)$ \\
\hline $\begin{array}{l}\text { I select information that is immediately } \\
\text { accessible. }\end{array}$ & $91(44.0)$ & $111(53.6)$ & $5(2.4)$ & $0(0)$ & $0(0)$ \\
\hline I carefully read the obtained information. & $91(44.0)$ & $110(53.1)$ & $6(2.9)$ & $0(0)$ & $0(0)$ \\
\hline $\begin{array}{c}\text { I use more than one source to satisfy my job } \\
\text { requirements. }\end{array}$ & $96(46.4)$ & $106(51.2)$ & $3(1.4)$ & $2(1.0)$ & $0(0)$ \\
\hline $\begin{array}{l}\text { I seek digital information when I want to } \\
\text { perform tasks in my working environment. }\end{array}$ & $104(50.2)$ & $97(40.9)$ & $4(1.9)$ & $2(1.0)$ & $0(0)$ \\
\hline $\begin{array}{l}\text { I select and use digital online information that } \\
\text { corresponds with my own opinions. }\end{array}$ & $114(55.1)$ & $90(43.5)$ & $3(1.4)$ & $0(0)$ & $0(0)$ \\
\hline $\begin{array}{l}\text { I seek digital online information when I want } \\
\text { to perform tasks in my working environment. }\end{array}$ & $113(54.6)$ & $82(39.6)$ & $9(4.3)$ & $3(1.4)$ & $0(0)$ \\
\hline
\end{tabular}

A CFA was conducted to validate the measurement of the information seeking behaviour and use. All five items yielded acceptable factor loadings, which ranged from 0.69 to 0.81 Figure 2. The fit indices for the information seeking behaviour and use CFA model were met (Table 5).

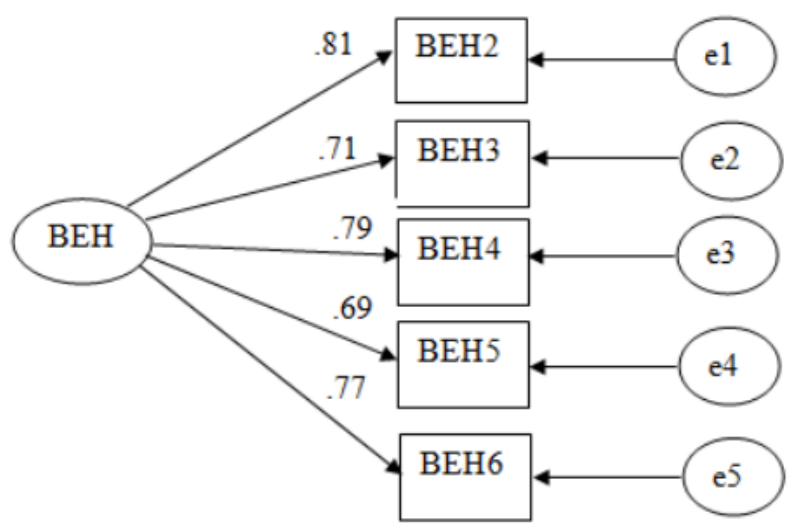

Figure 2 Measurement Model for information seeking behaviour and use

Table 5 Model Fit Indices for Information Seeking Behaviour Construct

\begin{tabular}{|c|c|c|c|}
\hline Indices & Value & Indices & Value \\
\hline Chi-Square & 4.171 & GFI & 0.992 \\
\hline DF & 4 & TLI & 0.999 \\
\hline Ratio & 1.043 & RMSEA & 0.014 \\
\hline P Value & 0.383 & & \\
\hline
\end{tabular}

\subsection{Effect of the digital literacy on the information seeking behaviour and use.}

The measurements obtained using the mediating variable (perceived usefulness) in the relationship between literacy and Digital Information Seeking Behaviour and use revealed no significant contributions at $\mathrm{R}^{2}=0.011$. In addition, the variables usefulness and literacy do not 
Effect of digital Literacy on information seeking behaviour among managers of telecommunication companies in Saudi Arabia

contribute; apart from literacy, which makes a slight contribution (Beta $=.06, \mathrm{p}=.00$ at .05 alpha level), (Table 6).

Table 6 Regression Analysis Model Coefficients Results for Mediation Effect of Usefulness on the Relation Between Literacy and Digital Information Seeking Behaviour

\begin{tabular}{|c|c|c|c|c|c|}
\hline & \multicolumn{6}{|c|}{ Regression model summary $\left(\mathbf{R}^{2}=\mathbf{0 . 0 0 1}, \mathbf{F}_{(2,204)}=\mathbf{0 . 0 5 2} ; \mathbf{p}=\mathbf{0 . 9 4 9 )}\right.$} \\
\hline & $\mathrm{B}$ & Std. Error & Beta & $\mathrm{t}$ & P value \\
\hline Literacy & 0.014 & 0.077 & 0.013 & .183 & .855 \\
\hline Ease of use & -0.019 & 0.062 & -0.022 & -.300 & .765 \\
\hline
\end{tabular}

An additional analysis with the mediating variable (perceived ease of use) in the relationship between literacy and digital information seeking behaviour and use also reveals no significant contributions with $\mathrm{R}^{2}=0.001$. The variables ease, and literacy do not make any contributions (Table 7).

Table 7 Regression Analysis Model Coefficients Results for Mediation Effect of Ease of Use on the Relation Between Literacy and Digital Information Seeking Behaviour

\begin{tabular}{|c|c|c|c|c|c|}
\hline & \multicolumn{5}{|c|}{ Regression model summary $\left(\mathbf{R}^{\mathbf{2}}=\mathbf{0 . 0 0 1}, \mathbf{F}_{(\mathbf{2}, \mathbf{2 0 4})}=\mathbf{0 . 0 5 2} ; \mathbf{p}=\mathbf{0 . 9 4 9}\right)$} \\
\hline & $\mathrm{B}$ & Std. Error & Beta & $\mathrm{t}$ & P value \\
\hline Literacy & 0.014 & 0.077 & 0.013 & 0.183 & 0.855 \\
\hline Ease of use & -0.019 & 0.062 & -0.022 & -0.300 & 0.765 \\
\hline
\end{tabular}

The findings for technical support and information seeking behaviour and use reveals inconsistencies with the proposed intervening variables "perceived ease of use" and "perceived usefulness", which are mediated in a causal chain. Technical support is conceived as an independent variable that predicts the impact on information seeking behaviour and use. All relationships among these variables of technical support were based on the research questions. The results indicate that the higher-order construct, which consists subconstructs like "information centre support", "technical experience", and "digital literacy", only supports some hypotheses.

\section{CONCLUSION}

This study investigates the factors that influence digital information seeking behaviour and use. The emergence of digital information disseminations in a digital knowledge-based system yielded improved skills and capabilities for both individuals and organisations in information use. The extensive selection of available electronic sources and channels range from e-mail to discussion lists, newswires, web logs, commercial online databases, in-house proprietary databases, corporate portals, company Intranets, the Internet, and Web browsers to connect to the World Wide Web. Channels of communication such as SMS and wi-fi zones, which facilitate the use of palm-held devices and laptops offer computer-mediated communication across time and space, enable information sharing. Video conferencing and telephones with pictures offer the ability to accumulate and transmit voluminous data and send and receive messages from large groups to prevent the delays caused by office memos and have spawned online social networks and the concept of accessing information anytime and anywhere. Regardless of whether the source is a personal, documentary, or electronic information source, each information source displays characteristics that render it appropriate for some situations and not others. As a result, the selection of appropriate information sources is a critical issue that managers are required to handle during their work. The need to filter and select the most 
appropriate sources and effectively manage information requirements is compounded due to the exponential rate of growth of literature via the diverse media, the resulting information overload, and the lack of knowledge and skills by managers to maximise the available resources.

The findings indicate a positive relation among "organisational factors", "individual profile", "technical support" with information seeking behaviour and use. The mediating effect of "perceived usefulness" and "perceived ease of use" exists; however, no positive relationship is obtained using the proposed mediating variables. The use of a single-informant method, a cross-sectional research design and a focus on four telecommunication companies in Saudi Arabia are the constraints of this study. Future studies should incorporate a multiple response method and a longitudinal design and should include samples of different telecommunication companies.

\section{LIMITATIONS}

A weakness of this methodology is the time lag at the point of implementation. Therefore, the direct causal effect cannot be inferred; however, the findings remain beneficial for understanding the relationships among the variables. Future studies should consider a longitudinal approach to overcome the shortcoming caused by the time lag in cross-sectional design.

\section{REFERENCES}

[1] Bilawar, P. B., Pujar, S. M., Librarian, A., \& Balasaheb, B. (2016). Impact of e-information literacy on information seeking behavior of university teachers. Annals of Library and Information Studies, 63, 176-181. Retrieved from http://nopr.niscair.res.in/bitstream/123456789/35697/1/ALIS 63\%283\%29 176-181.pdf

[2] Cooper, D. R., \& Schindler, P. S. (2003). Business research methods. Business. Retrieved from http://130.209.236.149/headocs/31businessresearch.pdf

[3] de Alwis, G. (2006). Transformation in managers' information seeking behaviour: a review of the literature. Journal of Information Science, 32(4), 362-377. http://doi.org/10.1177/0165551506065812

[4] Eshet-Alkalai, Y. (2004). Digital Literacy: A Conceptual Framework for Survival Skills in the Digital era. Journal of Educational Multimedia and Hypermedia. Retrieved from http://www.openu.ac.il/personal_sites/download/Digital-literacy2004-JEMH.pdf

[5] Ge, X. (2009). Information-Seeking Behavior in the Digital Age : A Multidisciplinary Study of Academic Researchers. Digital Age.

[6] Katz, I. R. (2007). Testing Information Literacy in Digital Environments: ETS's iSkills Assessment. Information Technology and Libraries, 26(3), 3. http://doi.org/10.6017/ital.v26i3.3271

[7] Long, C. M., \& Shrikhande, M. M. (2005). Improving information-seeking behavior among business majors. Research Strategies, 20(4), 357-369. http://doi.org/10.1016/j.resstr.2006.12.022

[8] Martin, A. (2008). Digital Literacy and the "Digital Society." In Digital literacies: Concepts, policies and practices (p. 321). http://doi.org/10.1093/elt/ccr077

[9] Noh, Y. (2017). A study on the effect of digital literacy on information use behavior. Journal of Librarianship and Information Science, 49(1), 26-56. http://doi.org/10.1177/0961000615624527 